\title{
Åndsforestillinger og deres enhed i Johannesevangeliet
}

\author{
Lektor, ph.d. \\ Jesper Tang Nielsen, Københavns Universitet
}

\begin{abstract}
Inspired by recent developments in Johannine research in Denmark, this article investigates the coherence of the concept of pneu$m a$ and paraklêtos in the Johannine writings. On the basis of the clear difference between pneuma and paraklêtos in First John, it differentiates between three different concepts in the Fourth Gospel. The first concerns Jesus' possession of the pneuma from the incarnation to the death on the cross. It derives from the synoptic tradition, or more probably directly from the Gospel of Mark. The second does not have parallels in the synoptic gospels. It concerns the role of the pneuma for the believers. All instances are connected with the ritual praxis in the community and have remarkable relations to Paul. The third conception includes the Paraclete-sayings and is probably a genuine Johannine invention. It presents the pneuma-paraclete as an active figure that takes the place of the absent Jesus and in many ways authorizes the gospel writing. It is furthermore argued that the logos of the prologue can be understood in specific Stoic terms. The Stoic understanding of logos as being the cognitive side of the material pneuma is able to comprise all aspects of the Johannine pneuma-paraclete even if it is a combination of different ideas. Therefore, the prologue should be understood as a philosophical introduction that makes the reader incorporate all three Johannine pneumata into one conception.
\end{abstract}

Keywords: Gospel of John - spirit - pneuma - paraclete - logos - Stoicism - prologue

Det er ikke uden grund, at Johannesevangeliet tidligt i kirkens historie blev betegnet "det åndelige evangelium". Enhver læser vil bemærke, at ånden og talsmanden, pneuma og paraklêtos, spiller en særlig rolle. To danske eksegeter har for nylig fremsat en vægtig tolkning af baggrunden for den johannæiske forestilling. ${ }^{1}$ De mener, at den

1. Gitte Buch-Hansen, "It is the Spirit that Gives Life." A Stoic Understanding of Pneuma in John's Gospel, BZNW 173 (Berlin/New York: De Gruyter 2010); Troels Engberg-Pedersen, John and Philosophy. A New Reading of the Fourth Gospel (Oxford: Oxford University Press 2017). De to bøger er enige om meget, men der er også mange forskelle. Ikke mindst betoner Buch-Hansen pneumas fysikalitet mere end Engberg-Pedersen. Jeg har anmeldt Engberg-Pedersens monografi i DTT 80 (2017), 51-69. Engberg-Pedersen har repliceret i DTT 80 (2017), 300-310. Dette 
johannæisk pneuma skal forstås på baggrund af stoisk filosofi. Særligt Troels Engberg-Pedersen har argumenteret for, at alle udsagn om pneuma og paraklêtos kan rummes inden for denne ene konception.

Ikke desto mindre finder jeg det værd at rejse spørgsmålet, hvordan denne enhed opstår. For mig at se bekræfter de johannæiske udsagn ikke umiddelbart, at der ligger én forestilling til grund. Jeg opfatter snarere den johannæiske pneuma-paraklêtos som et resultat af en fortolkningsproces, hvor Johannesevangeliet inddrager forskellige opfattelser af pneuma fra sin Kristus-troende sammenhæng og forsøger at samle dem under én forståelse. ${ }^{2}$ Prologen kan skabe denne enhed, hvis logos forstås filosofisk, som de to nævnte eksegeter foreslår.

I det følgende vil jeg prøve at vise, at der er forskellige forestillinger i evangeliets korpus, og hvordan de kan opfattes sammenhængende, hvis de læses med prologen som vejledning.

\section{Pneuma i menigheden: Første Johannesbrev}

Det er rimeligt at begynde med Første Johannesbrev. Brevet er nært forbundet med Johannesevangeliet både med hensyn til sprog og forestillingsunivers. Det er utvivlsomt blevet til i samme miljø som evangeliet. De kronologiske forhold mellem brev og evangelium er ikke klare, men brugen af pneuma og paraklêtos forekommer mindre sofistikeret i brevet end i evangeliet.

\subsection{Paraklêtos}

Ordet paraklêtos optræder kun én gang i Det Nye Testamente uden for Johannesevangeliet. Det er i Første Johannesbrev 2,1. Verset indgår i det første afsnit af brevkorpus $(1,5-2,2)$. Med udgangspunkt i den programmatiske beskrivelse af Gud som lys $(1,5)$ indleder forfatteren et afsnit om synd (1,6-2,2). I første del af afsnittet (1,6-10) er

bidrag skal ikke fortsætte diskussionen, men præsentere nogle overvejelser, som er resultat af min læsning af Engberg-Pedersens bog. I meget kortere form blev de præsenteret ved Collegium Biblicums Årsmøde 2018, København, d. 23. januar. Jeg takker Troels Engberg-Pedersen og resten af collegiet for diskussionen.

2. Mig bekendt er et sådant forsøg ikke gjort før. Selv om pneuma og paraklêtos selvsagt er centrale begreber i Johannesforskningen, kender jeg ikke til tolkninger, der tematiserer pneuma-forestillingernes forskellighed. I den nyeste litteratur er den johannæiske ånds-forståelse imidlertid ikke et hovedanliggende og slet ikke dens herkomst. Ud over de i note 1 nævnte danske bidrag er der ikke en aktuel diskussion om baggrunden for pneuma i Johannesevangeliet. Se Gary M. Burge, "The Gospel of John," Biblical Theology of the Holy Spirit, red. Trevor J. Burke \& Keith Warrington (London: SPCK 2014). 
hvert vers konstrueret med en konditionalsætning og en hovedsætning. Alle sætninger er formuleret i første person pluralis og inkluderer derfor principielt brevskriveren og hele menigheden, om end der tydeligvis ligger en polemik bag. ${ }^{3}$ Nogle konditionalsætninger (v. 6.8.10) udtrykker således en position, som brevskriveren tilskriver sine modstandere. De har ifølge forfatteren benægtet syndens realitet (Klauck 1991, 92). De mener hverken at have synd (v. 8) eller at have syndet (v. 10). I forfatterens øjne forkaster de dermed selve frelseshandlingen, der ifølge ham renser for synd og uretfærdighed (v. 7.9). Mens første del af afsnittet (1,6-10) handler om fortidige synder, behandler sidste del af afsnittet synd som en aktuel mulighed for de troende $(2,1-2)$ :

Mine børn, dette skriver jeg ikke til jer, for at I skal synde. Men hvis nogen synder, har vi en paraklêtos hos Faderen, Jesus Kristus, den retfærdige; han er et sonoffer (i $\lambda \alpha \sigma \mu$ ó $\varsigma$ ) for vore synder, og ikke blot for vore, men for hele verdens synder.

Eftersom forfatteren i det foregående både har betonet syndens realitet, bekendelsens nødvendighed og renselsens mulighed, finder han det nødvendigt at understrege, at dette ikke giver de kristne ret til at synde. Tværtimod. Men hvis nogen synder, optræder Jesus Kristus som paraklêtos hos Gud og kan i kraft af sit sonoffer formidle syndstilgivelse. ${ }^{4}$

I denne forestilling indsættes paraklêtos i en flerleddet relation: En suveræn magthaver (Faderen), en magtesløs undersåt (synderen) og paraklêtos (Jesus Kristus), der taler undersåttens sag over for suverænen, fordi forholdet til denne er brudt på grund af undersåttens fejltagelser (synd). D. Pastorelli har vist, at netop denne struktur er karakteristisk for antik jødiske anvendelser af termen paraklêtos, ikke mindst hos Filon. ${ }^{5}$ Når man således ikke ser den direkte baggrund i

3. Om modstanderne se fx Hans-Josef Klauck, Der erste Johannesbrief, EKK 23/1 (Neukirchen-Vluyn: Neukirchener Verlag 1991), 34-42.

4. Denne tolkning, der er den almindelige, forstår altså verset sådan, at det angår de kristnes synder (Klauck 1991, 102). Dermed opstår en direkte modsætning til den syndfrihed, som de kristne har ifølge 3,9. Problemet løses oftest ved at skelne mellem den ideale beskrivelse af den kristne som syndfri (jf. 3,9) og den realistiske karakteristik af de kristnes mulige synder (jf. 2,1). Man kan udbygge fortolkningen ved at sondre mellem den grundlæggende tvang til at synde, som de kristne ikke længere er underlagt, og de enkelte 'Tatsünden', som de endnu kan begå (smst.).

5. David Pastorelli, Le Paraclet dans corpus johannique, BZNW 142 (Berlin/New York: De Gruyter 2006), 102, om Filon se s. 66-86. Pastorelli kalder denne brug "composition dérivée" i modsætning til "composition paratactique" (se ndf.) og omtaler strukturen som en "triangle" (Pastorelli 2006, 102f). Det er selvfølgelig 
den traditionelle juridiske brug, er der heller ingen modsætning mellem v. $1 \mathrm{og}$ v. 2, som R. Bultmann påstod. ${ }^{6}$ Tværtimod forekommer det på baggrund af Filons brug af paraklêtos i forbindelse med rituelle handlinger (Spec.Leg. 1.237; Praem. 166f) ikke underligt, at det kobles sammen med Jesu universelle soningsoffer (i入 $\alpha \sigma \mu$ ós). Det er netop dette offer, der sætter ham i stand til at være paraklêtos. Den ide har en nær indholdsmæssig parallel i Jesus Kristus' funktion som intercessor over for Gud (Rom 8,34).

\subsection{Pneuma}

Termen pneuma optræder i tre sammenhænge i Første Johannesbrev. Første gang er den bevis på den såkaldt reciprokke immanens mellem Gud og de troende. Det lyder, at Gud har givet et bud om at tro på Jesus Kristus og elske hinanden $(3,23)$. Den, der overholder dette bud, bliver i Gud og Gud i ham (3,24a). At Gud bliver i dem, kan

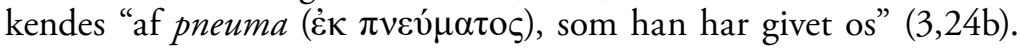
Nøjagtig den samme brug af pneuma findes i 4,13. Guds tilstedeværelse i den troende er således identisk med pneumaens tilstedeværelse i ham. Man kan ikke forstå det anderledes, end at pneuma helt i overensstemmelse med paulinske forestillinger er til stede såvel i den individuelle troende ( $\mathrm{fx} 1$ Kor 3,16 ) som i menighedens kollektiv ( $\mathrm{fx}$ 1 Kor 12,11).

Umiddelbart efter den tilkendegivelse af de troendes besiddelse af pneuma indfører forfatteren en sondring mellem forskellige pneumata, for ikke alle er fra Gud (4,1). Afsnittet 4,1-6 handler om be$\mathrm{d} ø$ mmelsen af disse pneumata. Forfatteren stiller to kriterier op. For det første bekender pneuma fra Gud Jesus Kristus kommet i kød ( $\dot{\varepsilon} v$ баркi) $(4,2)$. En pneuma, der ikke bekender Jesus, er ikke fra Gud,

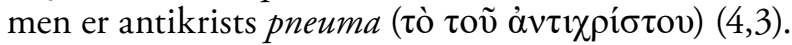

Man finder en parallel til dette kriterium for bedømmelse af pneumata hos Paulus. I Første Korintherbrev fremføres det netop, at

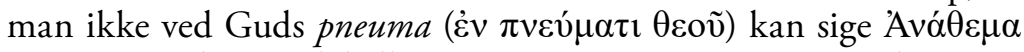

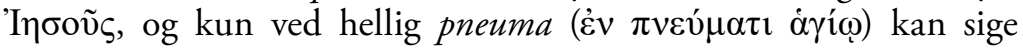

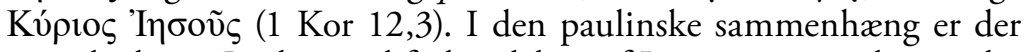
uenighed, om Paulus med forbandelsen af Jesus citerer et slogan, der har været anvendt af en gruppe i Korinth. ${ }^{7}$ Men i Første Johannesbrev synes det oplagt, at kriteriet er rettet mod en modstandergruppe, der

rigtigt, for så vidt tre agenter (en overordnet, en underordnet og paraklêtos) deltager, men der er faktisk flere elementer involveret i relationen, bl.a. det brudte forhold.

6. Rudolf Bultmann, Die Johannesbriefe, KEK 14 (Göttingen: Vandenhoeck \& Ruprecht 1967), 29f. Af den grund tilskrev han den kirkelige redaktor v. 2.

7. Jf. fx Joseph A. Fitzmyer, First Corinthians, Anchor Bible 32 (New Haven/London: Yale University Press 2008), $455 f$. 
tilsyneladende ikke bekender Jesus kommet i kød. Hvordan testen konkret har taget sig ud, er vanskeligt at vurdere. Det er muligt, at det er foregået som en bekendelseshandling i menigheden. I det tilfælde ville den enkeltes pneuma blive prøvet på, om vedkommende faktisk bekendte Jesus Kristus kommet i kød (jf. Klauck 1991, 234).

Næste kriterium tyder på, at noget sådant har foregået. For det er i virkeligheden en cirkelslutning (4,4-6): Forfatterens meningsfæller er af Gud; de har overvundet verden, fordi den Gud, der er i dem, er større end den Gud, der er i verden (4,4). Modstanderne derimod er fra verden og har succes i verden $(4,5)$. Med eftersom de ikke er af Gud, hører de ikke på forfatteren og hans tilhængere, for de er jo af Gud. De har kun succes blandt dem, der kender Gud (4,6a). Altså afslører modstanderne sig som vildfarne, fordi de ikke tilslutter sig forfatterens mening om sandhed. Således kender man sandhedens pneuma og vildfarelsens pneuma $(4,6 \mathrm{~b})$. Med andre ord afslører forholdet til forfatterens opfattelse, fx i bekendelseshandlingen, om man besidder vildfarelsens eller sandhedens pneuma.

I den sidste tekst optræder pneuma som vidne. Teksten indeholder to forskellige afsnit.

Han er den, der er kommet gennem vand og blod, Jesus Kristus. Han kom ikke med vandet, men med vandet og blodet; og det er pneuma, som vidner, fordi pneuma er sandheden $(5,6)$.

For der er tre, som vidner: Pneuma og vandet og blodet, og de tre

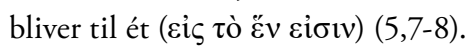

Bag det første afsnit kommer der atter en modposition til syne. Nogle mener, at Jesus Kristus kun kom med vand og ikke med blod. Sammenholder man den position med det billede af modstanderne, som er blevet præsenteret ovenfor, er det en nærliggende udlægning, at vandet refererer til Jesu dåb og blodet til hans død. Modstandersynspunktet skulle således være, at Jesus ved dåben fik ånden og således blev adopteret som Guds søn. For denne adoptianske kristologi skulle hans korsdød være uden betydning. Forfatteren understreger ved blodet det modsatte synspunkt: Døden, og det vil sige hans menneskelighed, har betydning (Klauck 1991, 295f). Det er det, som pneuma vidner om. Denne udlægning svarer til 4,2-3, al den stund pneuma i begge tilfælde er sandhed, fordi den vidner for Jesu Kristi menneskelighed.

I det andet afsnit bliver vandet og blodet gjort til vidner sammen med pneuma, og disse forbindes i en triade. I og med verset i modsætning til omtalen af Jesu komme i v. 6 taler i nutid, synes vandet og blodet at have en anden symbolsk værdi. Hvor de i v. 6 refererede 
til Jesu historie, har de i v. 7-8 en aktuel vidnestatus sammen med pneuma. Det kan kun være dåb og nadver, der på den ene side udspringer af Jesu virke (jf. Joh 19,34) og på den anden side er aktuelle realiteter i menigheden (Klauck 1991, 301). Når de tre kan være ét, må det være, fordi pneuma er medvirkende i de to ritualer. Det svarer til den opfattelse af dåb og nadver, som findes hos Paulus. Også hos ham er dåb og nadver nært forbundet med pneuma. Ifølge ham modtages pneuma ved dåben, og nadverelementerne kan beskrives som en åndelig drik (fx 1 Kor 12,13). ${ }^{8}$

Første Johannesbrevs forståelse af pneuma er altså direkte forbundet med menighedens konkrete praksis. Derfor er der mange ligheder med Paulus. Begge forfattere forholder sig til den måde, hvorpå pneuma var nærværende i de tidligste kristne menigheder, herunder gennem ritualerne. På samme måde udtrykker de en opfattelse af den himmelske Jesus Kristus som intercessor over for Gud. Sandsynligvis har også dette været en almindelig forestilling, men kun i Første Johannesbrev bruges termen paraklêtos. Den er til gengæld ikke forbundet med pneuma, som den bliver i Johannesevangeliet.

\section{Pneumata i teksten: Johannesevangeliets korpus}

Johannesevangeliet har en langt mere differentieret og kompliceret brug af såvel paraklêtos som pneuma end Første Johannesbrev. Man finder én gruppe udsagn, som har tydelige synoptiske paralleller. De omhandler alle Jesu besiddelse af pneuma. Desuden findes én gruppe, som ifølge ordlyden ikke har direkte paralleller i Det Nye Testamente. De har derimod alle relation til den religiøse praksis i menighederne og har derfor indholdsmæssig sammenhæng med bl.a. Paulus. Endelig er der én særlig johannæisk gruppe med paraklêtos-udsagn, som er direkte forbundet med pneuma. Den identificeres som hellig pneuma og sandhedens pneuma.

\subsection{Jesus og pneuma}

Johannesevangelisten har overtaget en narrativ struktur fra Markusevangeliet, hvor pneuma optræder på centrale steder, nemlig både ved

8. Det liturgiske led epiklese, hvor helligånden 'nedbedes' over brød og vin, er senest med Hippolyts kirkeordning fra tredje århundrede en integreret del af nadverliturgien. Bent Flemming Nielsen, På den forste dag. Kirkens liturgi: Oldtid og Middelalder (København: Eksistensen 2017), 90.166. 
indledningen af Jesu offentlige virksomhed og ved korsfæstelsen. ${ }^{9}$ Hertil kommer to eksempler på, at pneuma optræder "antropologisk", samt en omtale af Jesu besiddelse af Guds pneuma.

\subsubsection{Jesu "dåb"}

Markusevangeliet indledes med Johannes Døberens forkyndelse og dåben af Jesus (Mark 1,1-13). Markus' version af Johannes Døberens forkyndelse lyder:

"Efter mig (ỏ

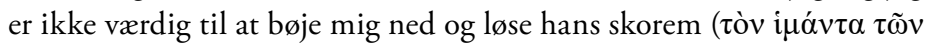

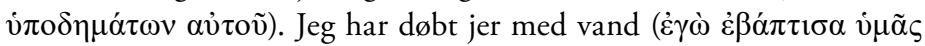

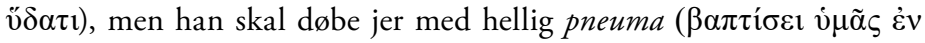
$\pi v \varepsilon u ́ \mu \alpha \tau \imath \dot{\alpha} \gamma i ́ \omega) "($ Mark 1,7f).

Derefter berettes det om Jesu dåb (Mark 1,9-11). Han kommer til Johannes og bliver døbt af Johannes i Jordan:

Straks da han steg op af vandet, så han himlene flænges og pneumaen

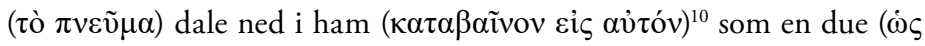
$\pi \varepsilon \rho ı \tau \varepsilon \rho \alpha \grave{\alpha} v)$; og der lød en røst fra himlene: "Du er min elskede søn, i dig har jeg fundet velbehag” (Mark 1,10f).

Som bekendt er portrættet af Johannes helt anderledes i Johannesevangeliet, hvor han end ikke kaldes "Døberen”. Imidlertid er der også ligheder med det markinske billede. I Johannesevangeliet bliver Johannes spurgt, om han er Kristus eller Elias eller profeten $(1,25)$. Han svarer:

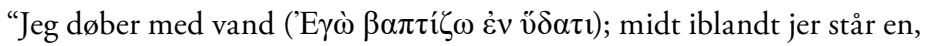
som I ikke kender, han som kommer efter mig (ó ỏ $\pi i ́ \sigma \omega \mu$ ov), og hans skorem er jeg ikke værdig til at løse ( $(1,26 f)$.

Senere i perikopen vidner Johannes:

9. Opfattelsen af forholdet mellem Johannesevangeliet og synoptikerne har ændret sig ofte gennem forskningshistorien. I dag er der en vis konsensus om, at Johannesevangelisten har kendt Markusevangeliet og formodentlig Lukasevangeliet, se min "Johannes und Lukas. Szenen einer Beziehung." Rewriting and Reception in and of the Bible, FS Mogens Müller, red. Jesper Høgenhaven, Jesper T. Nielsen \& Heiko Omerzu, WUNT 396 (Tübingen: Mohr Siebeck 2018), 125-162.

10. Flere håndskrifter læser غ̇ं 'av่ óv. Ifølge Nestle-Aland er det på grund af påvirkning fra parallelstederne i Matthæus- og Lukasevangeliet. 


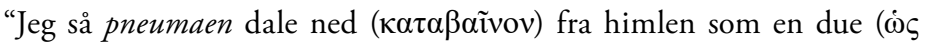

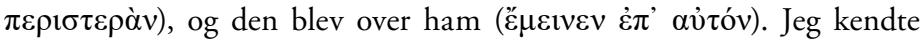
ham ikke, men han, som har sendt mig for at døbe med vand, han sagde til mig: Det er ham, du ser pneumaen dale ned over og blive over

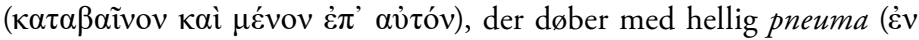
$\pi v \varepsilon v ́ \mu \alpha \tau \imath \dot{\alpha} \gamma i ́())$. Jeg har set det, og jeg har aflagt det vidnesbyrd, at han er Guds søn” (1,32-34).

Johannesevangelisten har overtaget forestillinger og formuleringer fra Markusevangeliet, men samtidig er scenen helt omkalfatret. Den væsentligste ændring er, at det ikke fortælles, at Jesus døbes. Hvor dåben i Markusevangeliet er fortalt fra Jesu perspektiv og inkluderer en udnævnelse af ham som Guds søn, anlægges i Johannesevangeliet Johannes' perspektiv. Johannes ser pneumas nedstigen over Jesus. Den fungerer som en udpegning, så Johannes kan vidne, at Jesus er Guds søn.

Johannesevangeliets version af mødet mellem Johannes og Jesus bevidner en gennemgående tendens i fremstillingen af Johannes. Evangeliet ønsker at nedtone hans rolle til vidnefunktionen alene. Det er allerede tilfældet i den første henvisning til Johannes i prologen (1,6-8), hvor det understreges positivt, at han er menneske, og at han kommer for at vidne, mens det pointeres negativt, at han ikke selv er lyset. Således følger det af hans vidnesbyrd, at der er et utvetydigt rangforhold mellem ham og Jesus $(1,15.30)$. Han afviser eksplicit at være Kristus, Elias eller profeten (1,19-22). Han er blot stemmen af en, der råber i ørkenen $(1,23)$, hvilket i sig selv er en nedskrivning af hans rolle i forhold til beskrivelsen i Markusevangeliet, hvor han faktisk er en forløber, der baner Herrens vej (Mark 1,2-4). Således er hans rolle ikke blot tydeligt underordnet Jesus, det er også gjort klart, at han ikke har nogen selvstændig funktion i forhold til ham. Det understreger han selv tydeligt, når han siger, at hans funktion er i forhold til Israel (1,30-32). Han vidner blot $(1,6-8.15 ; 5,33.35)$. Tendensen kulminerer i Johannes' bekendelse af sin underlegenhed (3,27-30). Nedskrivningen af Johannes er kristologisk begrundet. Den johannæiske Jesus har ikke brug for en menneskelig forløber eller mellemmand. Netop af den grund kan Johannesevangeliet ikke fortælle, at han døber Jesus. Det ville anfægte den kristologiske rolle som Guds søn, hvis han skulle gennem Johannes' vanddåb. Derfor sker pneumas nedstigen ikke for hans skyld, men for Johannes' skyld, 
så han overfor Israel kan vidne, at Jesus døber med hellig pneuma og er Guds søn (1,33f). ${ }^{11}$

Det har også konsekvenser for pneumas rolle i perikopen. Pneu-

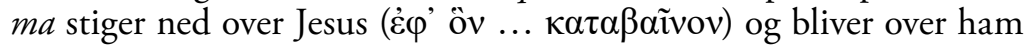

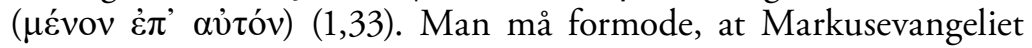
fungerer som intertext for den johannæiske fortælling. Det vil sige, at den markinske beretning om Jesus og Johannes Døberen bliver aktiveret hos læseren gennem Johannesevangeliets tydelige referencer. Men intertexten fremhæver i dette tilfælde forskellene. Netop på baggrund af Markusevangeliet kan man se, at Johannesevangeliet fortier Jesu dåb, og at pneumaen ikke kommer over Jesus for hans skyld. ${ }^{12}$

\subsubsection{Han giver pneuma uden mål}

$3,34 \mathrm{~b}$ er et vanskeligt vers, fordi kommentatorerne er delte om, hvem der er subjektet. Det lyder "for han giver pneumaen uden mål."13

Spørgsmålet er, om det er Gud eller Jesus, der giver; og sammenhæn nende dermed om det er Jesus eller mennesker, der modtager. I første tilfælde er det en bekræftelse af, at Jesus bærer pneuma; i andet tilfælde bekræfter det, at han døber med pneuma. Sprogligt lader det sig ikke afgøre. ${ }^{14}$ Imidlertid er det af tre grunde mest overbevisende, at Gud er subjektet. For det første indledes halvverset med konjunktionen $\gamma \grave{\alpha} \rho$, hvorved det får karakter af en begrundelse for det foregående halvvers. Altså: "Den, Gud har sendt, taler Guds ord ( $\rho \eta \dot{\mu} \mu \tau \alpha)$, for han giver pneuma uden mål." Det svarer for det andet til 6,63b, at Jesu ord ( $\dot{\eta} \eta \alpha \tau \alpha)$ er pneuma. For det tredje fortsætter talen med endnu en sætning, hvor Gud er subjekt $(3,35)$. Af den grund ville det være mærkeligt med et subjektskifte mellem 3,34a og 3,35.

11. I Matthæus- og Lukasevangeliet spores den samme forlegenhed ved Jesu dåb hos Johannes Døberen. Matthæusevangeliet løser det ved at lade Johannes Døberen sige eksplicit, at han selv har brug for at blive døbt af Jesus - ikke omvendt (Matt $3,14)$, hvorefter Jesus overtaler ham til at "opfylde al retfærdighed" (3,15). Dåben selv er omstruktureret til en proklamation, idet stemmen fra himlen siger "Denne er min søn, den elskede, i ham har jeg velbehag” (Matt 3,17). Lukasevangeliet beholder den markinske version med en tiltale til Jesus, men fortæller om Johannes Døberens fængsling før dåben $(3,18-20)$ og gengiver selve dåbshandlingen i en absolut genitiv $(3,21)$, så det ikke eksplicit fremgår, at Johannes Døberen døbte Jesus. 12. En tilsvarende kritisk relation til den markinske intertext findes eksplicit tre andre steder i Johannesevangeliet $(3,25 ; 12,27 ; 18,11)$.

13. Udtrykket oủ ... غ̇א $\mu \dot{\varepsilon} \tau \rho o v$ er en litote. Hans-Christian Kammler oversætter det endnu mere pointeret 'i utømmelig fylde', Kammler, "Jesus Christus und der Geistparaklet. Eine Studie zur johanneischen Verhältnisbestimmung von Pneumatologie und Christologie." Otfried Hofius \& Hans-Christian Kammler, Johannesstudien. Untersuchungen zur Theologie des vierten Evangeliums, WUNT 88 (Tübingen: J.C.B. Mohr (Paul Siebeck)) 1996, 87-211 (170).

14. Mod Kammler (1996), 171-173. 
I den fortolkning er verset simpelt hen en forklaring på, at Jesus taler Guds ord. Det gør han, fordi han har pneuma. Af den grund er hans ord pneuma, som det vil fremgå af 6,63b.

\subsubsection{Jesu død}

I Johannesevangeliet overgiver ( $\pi \alpha \rho \varepsilon ́ \delta \omega \kappa \varepsilon v)$ Jesus pneumaen på korset $(19,30)$. I Markusevangeliet udånder ( $\dot{\varepsilon} \xi \dot{\varepsilon} \pi v \varepsilon v \sigma \varepsilon v)$ han (Mark 15,37; jf. Luk 23,46). Ligesom i forbindelse med dåbsscenen kan man i korsscenen spore en kristologisk udvikling. Hos Markus skal verbet formentlig blot markere hans død. Hos Johannes understreges Jesu suverænitet. ${ }^{15}$ Verbet omformes til en aktiv handling: Jesus overgiver selv pneuma i dødsøjeblikket.

Ikke desto mindre markerer udsagnet netop hans død ligesom den markinske udånding. På baggrund af den markinske intertext bliver det derfor tydeligt, at den johannæiske Jesus ikke blot udånder, men selv er autoritet over sit liv og død og suverænt overgiver pneumaen til Gud og derfor dør.

\subsubsection{Jesu indre liv}

To steder virker pneumaen i Jesus; først da han bevægedes i pneumaen

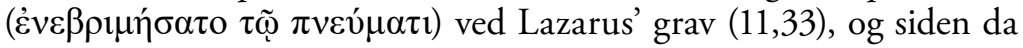

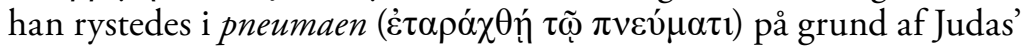
forræderi $(13,21)$. I Markusevangeliet, men interessant nok ikke i de synoptiske paralleller, er der to tilsvarende udtryk: Da Jesus kendte

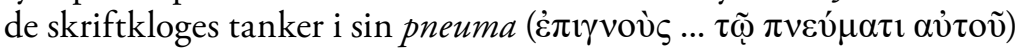
(Mark 2,8; jf. Matt 9,4; Luk 5,22), og da han sukkede i sin pneuma

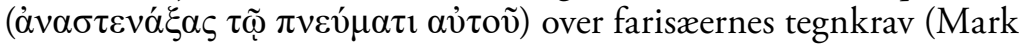
8,12; jf. Matt 16,2).

Naturligvis kan man ikke tale om direkte paralleller mellem de markinske og johannæiske udsagn. Men de markinske rummer en "antropologisk" forståelse af pneuma, som betegnelse for menneskets indre liv. ${ }^{16}$ Denne forståelse er parallel med den johannæiske forståelse af pneuma som det, der driver Jesu reaktioner på død og forræderi. Det er ikke usandsynligt, at Johannesevangelisten fra Markusevangeliets "antropologiske" udsagn har antaget den opfattelse, at pneuma kan udvirke indre aktivitet i Jesus.

15. Hos de to andre synoptikere opgiver ( $\dot{\alpha} \varphi \tilde{\eta} \kappa \varepsilon v)$ han pneumaen (Matt 27,50) eller overlader $(\pi \alpha \rho \alpha \tau i ́ \theta \varepsilon \mu \alpha \mathrm{l})$ den (Luk 23,46). Disse fortolkninger af Markus' version fremviser en tendens til at præsentere Jesus som mere suveræn på korset, end han er i Markusevangeliet. Tendensen kulminerer i Johannesevangeliet.

16. Jf. fx Joel Marcus, Mark 1-7, Anchor Bible 27 (New York et al.: Doubleday 1999), 217. 


\title{
2.2. Pneuma hos de troende
}

Ud over Jesu besiddelse af pneuma er der en række udsagn i Johannesevangeliet, der omhandler de troende og pneuma. Deres relation til pneuma bliver i Johannesevangeliet fremstillet som en konsekvens af Jesu virke. Man finder ingen paralleller i de andre evangelier, men saglige sammenhænge med paulinske forestillinger.

\subsubsection{Fødsel med vand og pneuma}

I dialogen med Nikodemus udspiller sig følgende ordveksling:

\begin{abstract}
Jesus svarede ham: "Sandelig, sandelig siger jeg dig: Den, der ikke bliver

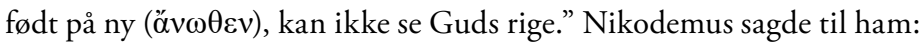
"Hvordan kan et menneske fødes, når det er gammelt? Det kan da ikke for anden gang komme ind i sin mors liv og fødes?" Jesus svarede: "Sandelig, sandelig siger jeg dig: Den, der ikke bliver født af vand og pneuma

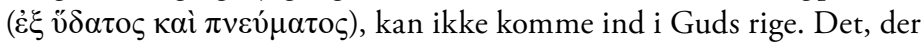
er født af kødet, er kød, og det, der er født af pneuma, er pneuma. Du skal ikke undre dig over, at jeg sagde til dig: I må fødes på ny (光 $\omega \theta \varepsilon v)$. Vinden blæser, hvorhen den vil, og du hører den suse, men du ved ikke, hvor den kommer fra, og hvor den farer hen. Sådan er det med enhver, som er født af pneuma” (3,3-8).
\end{abstract}

Der er almindelig enighed i forskningen om, at den johannæiske fødsel af vand og pneuma er en reference til dåben. Det bedste bevis er næsten, at R. Bultmann mente, at ordene ex hydatos stammede fra den kirkelige redaktor, som ville bringe teksten i overensstemmelse med kirkens praksis. ${ }^{17}$ Foretager man ikke den slags litterærkritiske operationer, finder fødslen anôthen sted i dåben. ${ }^{18}$ Men det er et spørgsmål, hvordan den skal forstås.

Inden for nyere kønshermeneutisk eksegese har flere eksegeter understreget fysikaliteten i de johannæiske udsagn om fødsel. ${ }^{19}$ Særligt på baggrund af antikke filosofiske og medicinske teorier argumenteret imod en symbolsk forståelse og i stedet hævdet, at de troendes fødsel som Guds børn er en konkret fødsel. Aristoteles og andre opfatter mandens sæd som en opløsning af vand og pneuma (Gen.

17. Rudolf Bultmann, Das Evangelium des Johannes, KEK 4 (Göttingen: Vandenhoeck \& Ruprecht 1941), 98 n. 2.

18. Ordspillet på anôthen bruges til at vise, at Nikodemus ikke forstår Jesus. Han opfatter det som en ny kødelig fødsel fra en moder, mens det ifølge Jesus betyder en ny åndelig fødsel uden moder, da den er fra oven.

19. Adele Reinhartz, "'And the Word Was Begotten': Divine epigenesis in the Gospel of John," Semeia 85 (1999), 83-103; Turid K. Seim, "Descent and Divine Paternity in the Gospel of John: Does the Mother Matter?” NTS 51 (2005), 361-375; Buch-Hansen (2010), 177-216. 
An. 735b35). Pneuma var det stof, der var i stand til at skabe barnet. Moderen bidrog blot med materien, mens faderens pneuma var det egentlige liv- og formgivende princip. Jo stærkere pneumaen var, jo mere fuldendt blev barnet. Derfor er fødslen ved Guds pneuma fra oven uden deltagelse af moderlig materie naturligvis den perfekte fødsel som skaber Guds børn.

Derfor må man følge G. Buch-Hansens udlægning af 3,8. Verset omhandler de troende som genfødte af pneuma. Det er gennem deres stemme ( $\varphi \omega v \eta \dot{)})$, at pneuma kommer til udtryk. Og det er oprindelsen og formålet i dette fænomen, der er ukendt (Buch-Hansen 2010, 307). Det tydeliggøres ved, at det netop er for Nikodemus, der personificerer den ikke-troende jøde, at pneumas virke er mysteriøst (jf.

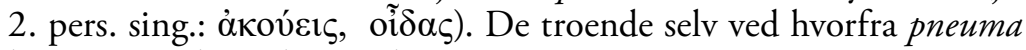
kommer, og hvor den går hen.

I denne læsning er den johannæiske Jesu udsagn en udlægning af dåben, som den foregår i menigheden. Vand og pneuma er forbundet i dåbsritualet (jf. 1 Joh 5,8). Dåbsvandet skal opfattes som den opløsning af vand og pneuma, hvorigennem Guds børn avles, der har Guds sperma i sig (1 Joh 3,9). Om end den konkrete fysikalitet ikke er så eksplicit hos Paulus, er det klart, at han også bevidner, at menighedernes dåbsritualer blev anset for at gøre de døbte til Guds børn ved overgivelsen af pneuma (jf. sammenhængen Gal 3,14; 3,2629; 4,5-7) (Engberg-Pedersen 2017, 323). Endvidere kan man se en parallel mellem det forhold, at pneuma giver sig udtryk i de pneumafødtes stemme, og de pneumatiske gudsdyrkelsesformer i de paulinske menigheder (jf. fx 1 Kor 12,1-11 og omtalen af de uforstående ikketroende i 1 Kor 14,23).

\subsubsection{Tilbedelse i pneuma og sandhed}

I sin dialog med den samaritanske kvinde bliver den johannæiske Jesus spurgt om det rette sted for gudsdyrkelse, Garizim eller Jerusalem $(4,20)$. Han svarer: Ingen af stederne, for den rette gudsdyrkelse sker i pneuma og sandhed $(4,23)$ og tilføjer:

“Gud er pneuma ( $\pi v \varepsilon \tilde{v} \mu \alpha$ ó $\theta \varepsilon o ́ \varsigma)$, og de, der tilbeder ham, skal tilbede ham i pneuma og sandhed" $(4,24)$.

I Johannesevangeliet skal dette udsagn selvfølgelig først og fremmest markere, at den rette gudsdyrkelse ikke er bundet til en lokalitet. Det afgørende for gudsdyrkelsen er, at den er står i forbindelse med Gud. ${ }^{20}$

20. Buch-Hansen betoner med rette sammenhængen til fødslen af vand og pneu$m a$. Den skal nemlig generere sønner, der svarer til gudsdyrkelsen i pneuma (BuchHansen 2010, 426). 
Dét er den, når den foregår i pneuma, for Gud er pneuma. På den ene side er forbindelsen mellem gudsdyrkelse og pneuma formentlig helt i overensstemmelse med menighedernes opfattelse af deres tilbedelsesform. Således er det gennemgående træk i Paulus' beskrivelse af korinternes forskellige gaver, at de foregår i den samme ånd (1 Kor 12,4-11). Det er helt ukontroversielt at sige, at de tidligste kristne menighedssammenkomster oplevede pneumas konkrete nærvær. På den anden side bevidner beskrivelsen af Gud som pneuma det mest filosofiske gudsbillede i Det Nye Testamente. Det svarer fuldstændig til stoikernes opfattelse af pneuma som det guddommelige stof, der gennemstrømmer alting og er identisk med Gud i den forstand, at Gud er den komplette koncentration af ren pneuma. Så filosofisk er Johannesevangeliets udsagn, at Origenes i sin kommentar til Johannesevangeliet måtte argumentere imod netop forståelsen af en materiel pneuma (13.123-153).

\subsubsection{Pneuma gør levende}

Johannesevangeliets sjette kapitel er den johannæiske version af bespisningsunderet og vandringen på søen (jf. Mark 6,35-52). Brødunderet følges op af en lang tale, hvor den johannæiske Jesus identificerer brødet med sig selv og til slut med sit kød og blod (6,52-58). Atter er der ingen tvivl om, at den sidste perikope refererer til nadveren. Netop af den grund tilhørte den ifølge Bultmann den kirkelige redaktion (Bultmann 1941, 174-177). Efter perikopen følger endnu en tale af Jesus. I den siger han:

“pneumaen er den, der gør levende. Kødet ( $\sigma \grave{\alpha} \rho \xi)$ gavner intet. De ord (’’́j $\mu \tau \alpha)$, som jeg har talt til jer, er pneuma og liv” $(6,63)$

Der er flere mulige tolkninger. Enten handler verset om kristologi og angår Jesu identitet. Det er således det direkte svar på Jesu spørgsmål i foregående vers: "Forarger dette jer. Hvad så, hvis I ser menneskesønnen stige op, hvor han var før?” (6,61f). Udsagnet skulle i så fald være en tilkendegivelse af, at Jesu fysiske fravær ikke burde forarge disciplene, fordi de har fået den livgivende pneuma gennem hans ord (jf. 6,68). En anden tolkning trækker forbindelsen til brødtalen. I så fald er det oplagt at se en sammenhæng med nadveren. Jesus siger så, at under hans fravær vil de have adgang til pneuma gennem nadveren, for den er ikke blot sarx, men pneuma i kraft af hans ord. Denne 
udlægning svarer til Paulus' opfattelse af nadveren som et pneumatisk måltid (1 Kor 12,13; jf. 1 Joh 5,8). ${ }^{21}$

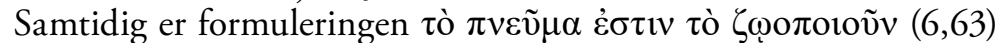
en ligeså filosofisk beskrivelse af pneuma som $\pi v \varepsilon \tilde{u} \mu \alpha$ ó $\theta \varepsilon o ́ \varsigma(4,24)$. Som beskrevet er pneuma i stoikernes tanke det livgivende princip, der gennemstrømmer alt levende. Uden den livgivende, guddommelige pneuma er der slet intet liv. Uanset om man finder den "kristologiske" eller "sakramentale" forståelse af 6,63 mest overbevisende, er meningen, at pneuma formidles gennem Jesu ord. Sarx, hvad enten det er Jesu eller nadverens sarx, gavner intet i sig selv. Har sarx værdi er det kun, for så vidt den er forenet med den livgivende pneuma.

\subsubsection{Pneuma fra hans indre}

En af de problemfyldte perikoper i Johannesevangeliet er 7,37-39. Det foregår under løvhyttefesten (jf. 7,2) på dens sidste dag. Her råber Jesus op og siger:

\footnotetext{
"Hvis nogen tørster, skal han komme til mig; og den, der tror på mig, skal drikke. Ligesom skriften siger: "Fra hans indre skal der rinde strømme af levende vand”." Dette sagde han om pneumaen, som de, der kom til tro på ham, stod i begreb med at modtage. For pneuma var der endnu ikke, da Jesu endnu ikke var herliggjort $(7,38 \mathrm{f})$
}

En vanskelighed ved perikopen er delingen mellem versene. I NestleAland 28 har man valgt at sætte punktum ved slutningen af v. $38 \mathrm{og}$ dermed lade participialkonstruktionen i begyndelsen af v. 39 høre sammen med dette vers. På den måde kommer skriftcitatet i v. 39 til at omhandle den troende: Fra hans indre skal der rinde strømme af levende vand. I min oversættelse har jeg valgt modsat. Jeg har placeret punktum efter participialkonstruktionen i begyndelsen af v. 39, hvorved det hører sammen med v. 38. Dermed bliver det eksplicit den troende, som skal drikke af Jesu vand i v. 38 (jf. 4,10.14). Skriftcitatet i v. 39 handler i så fald om Jesus: Fra hans indre skal der rinde strømme af levende vand (jf. 19,34). Denne løsning forekommer mig bedst, ikke mindst fordi skriften i Johannesevangeliet handler om Jesus (jf. 5,39).

Imidlertid er der en mængde andre problemer med skriftcitatet, al den stund det ikke findes ordret i nogen versioner af Det Gamle Testamente. For mig at se er den bedste løsning, at det refererer til skriftsteder fra Ezekiel 47,1-10, da denne tekst om strømmende floder

21. Jf. Engberg-Pedersen (2017), 101 med n. 32. Det er dog de færreste, der forstår 6,63 i relation til den eukaristiske del af brødtalen (6,51c-58). De fleste ser en modsætning mellem perikoperne. 
fra det eskatologiske tempel indgår i fejringen af løvhyttefesten ifølge rabbinske traditioner (M.Suk. 4,9f; T.Suk. 3,3-10). Dermed bliver versene endnu et eksempel på, at den johannæiske Jesus overtager templets rolle $(2,21){ }^{22}$

Der synes ikke at være tvivl om, at udsagnet om pneuma i 7,39 både narrativt og tematisk er bundet sammen med gudsdyrkelse. Tolkningen ligger lige for, at pneuma er til stede ved menighedens rituelle sammenkomster, hvor den i kraft af sit udspring hos den herliggjorte Jesus sikrer en gudsdyrkelse, der er kongruent med dens objekt (jf. $4,23 f)$.

\subsubsection{Pneuma til syndsforladelse}

Det sidste udsagn i denne gruppe falder ved den første opstandelsestilsynekomt, hvor den opstandne Jesus kommer til disciplene, mens dørene er lukkede $(20,19-23)$. Da de har set hans korsmærker og af den grund er blevet glade, sender Jesus dem, som han selv er blevet sendt $(20,21$; jf. 17,17-19).

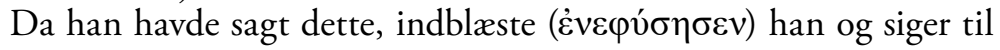
dem:

Modtag pneuma hagion. Forlader I nogen deres synder, er de dem forladt, nægter I at forlade nogen deres synder, er de ikke forladt (20,22-23)

Det er åbenlyst, at pneuma her er forbundet med menighedslivet, for så vidt den umiddelbart forbindes med syndsforladelse. ${ }^{23}$ Selv om denne praksis ikke andre steder i Det Nye Testamente er eksplicit forbundet med pneumas tilstedeværelse i menigheden, ligger det snublende nær i Første Johannesbrev, hvor Jesus som paraklêtos forbindes med syndstilgivelse (1 Joh 1,8-2,2). Det forekommer derfor utvetydigt, at disciplenes pneuma-besiddelse giver dem kompetence til syndstilgivelse i Jesu sted (jf. 1 Joh 2,12).

Anette Weissenrieder har på grundlag af antik medicinsk litteratur tolket dette vers inden for den omtalte retning, der betoner fysikali-

22. Jf. Mary L. Coloe, God Dwells with Us. Temple Symbolism in the Fourth Gospel (Collegeville: The Liturgical Press 2001. Christina Petterson viser, at det er Jesus som nærværende i Johannesevangeliets tekst, der overtager templets funktion. Petterson, From Tomb to Text. The Body of Jesus in the Book of John (London \& New York: T\&T Clark 2017), 97-113.

23. Jf. Michael Theobald, "'Wie mich der Vater gesandt hat, so sende ich euch' (Joh 20,21). Missionarische Gestalten im Johannesevangelium”, Studien zum Corpus Iohanneum, WUNT 267 (Tübingen: Mohr Siebeck 2010), 472-489 (488). Ifølge Theobald har hele scenen 20,19-23 karakter af gudstjeneste. Derfor er disciplene repræsentanter for menigheden, der i kraft af pneuma gives fuldmagt til initiation (smst.). 
teten i de troendes fødsel som Guds børn. Hun har påvist, at emphysan er forbundet til antik embryologi. Verbet anvendes i medicinsk litteratur gerne i forbindelse med pneuma og betegner en afgørende indblæsning af luft til fosteret. ${ }^{24}$ Hertil kommer, at det også anvendes af LXX i Gen 2,7, hvor Gud indblæser livsånde ( $\pi$ voฑ́) i mennesket. I den filosofisk orienterede Salomos Visdom refereres der til denne formulering i 15,11, hvor pnoê erstattes af pneuma. Man kan sige, at Johannesevangeliet følger samme filosofiske udlægning i sin reference til Gen 2,7. Johannesevangeliet spiller i 20,22f på skabelsesberetningen, men gør det på en måde, der understreger den konkrete medicinske forestilling om avling af afkom (Weissenrieder 2015, 150f.). Ved at indblæse pneuma gør Jesus disciplene til Guds børn og sætter dem dermed i stand til at tilgive synder. Dermed bliver også denne konkrete menighedspraksis funderet i pneumas tilstedeværelse.

\subsection{Paraklêtos}

Betegnelsen paraklêtos optræder i fem sammenhænge i Johannesevangeliet. ${ }^{25}$ De befinder sig alle inden for afskedstalekomplekset $(14,16 f .26 ; 15,26 ; 16,7-11.13)$. Det er ikke svært at se, at paraklêtos skal være garant for fortsættelsen af Jesu virke på en sådan måde, at det kommer til sin fulde udfoldelse.

\subsubsection{En anden paraklêtos, sandheds pneuma $(14,16 \mathrm{f})$}

Den johannæiske Jesus lover at bede faderen, så han skal sende en anden paraklêtos til dem, som skal være med dem til evig tid $(14,16)$. Betegnelsen "en anden" (ő̀ $\lambda \lambda \mathrm{ov})$ viser, at paraklêtos skal træde i Jesu sted. Den er sendt fra faderen, som Jesus er sendt (fx 10,36); men i modsætning til ham vil den ikke forlade dem. Næste vers giver en nærmere bestemmelse:

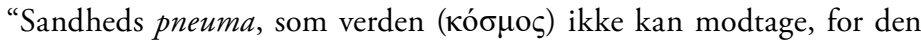
hverken ser den eller kender den. I kender den, for den bliver hos jer

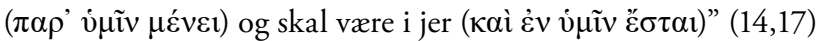

24. Annette Weissenrieder, "The Infusion of the Spirit: The meaning of $\dot{\varepsilon} \mu \varphi v \sigma \alpha \dot{\omega} \omega$ in John 20:22-23." The Holy Spirit, Inspiration, and the Cultures of Antiquity. Multidisciplinary Perspectives, red. Jörg Frey \& John Levison, Ekstasis: Religious Experience from Antiquity to the Middle Ages 5 (New York/Berlin: De Gruyter 2014), 119-151 (134).

25. Pastorelli opfatter brugen af paraklêtos i evangeliet anderledes end i brevet. I evangeliet er baggrunden "composition paratactique", dvs. betegnelsens ordrette betydning af "tilkaldt" er i fokus, så det kan antage betydning af "en tilforordnet", "en budbringer" eller "en repræsentant". Pastorelli finder særligt denne brug i den antikke græske litteratur, ofte er den forbundet med en moralsk kvalificering. Pastorelli (2006), $103 f$. 
Fordi der ikke er en hovedsætning, må udsagnet opfattes som en apposition til paraklêtos i det foregående vers. Samtidig fortsættes parallellen til Jesus, idet kosmos ikke kan modtage den, ligesom kosmos er i opposition til den johannæiske Jesus (fx 8,23), mens disciplene kan modtage den.

\subsubsection{Paraklêtos, hellig pneuma, skal lære og minde $(14,26)$}

I dette vers knyttes appositionen pneuma hagion til paraklêtos, som endvidere tilskrives aktive verber. Den får en selvstændig og aktiv rolle over for disciplene. Det viderefører parallellen til Jesus, hvilket understreges af, at den skal sendes i hans navn. Dens funktion er:

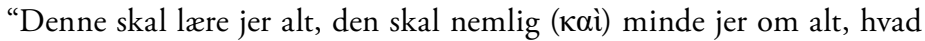
jeg har sagt til jer” $(14,26)$

Paraklêtos skal optræde som læremester. Dens objekt er i første del "alt" $(\pi \alpha ́ v \tau \alpha)$. Jeg vælger at opfatte det efterfølgende kai epexegetisk (BDR \$442,9), så det ikke tilføjer noget, men definerer, hvad dette "alt" er, og hvordan undervisningen skal finde sted. Det skal nemlig ske, når den minder ( sagt. Ved termen hypomnêskein indgår verset i det johannæiske tema

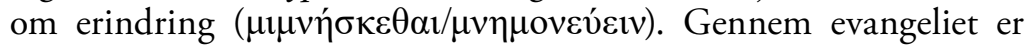
der flere udsagn om en erindring, der skal foregå efter Jesu død og opstandelse $(2,17.22 ; 12,16 ; 15,20 ; 16,4 ; 16,21)$. I hvert tilfælde er der tale om, at der vil være en erkendelsesmæssig gevinst i erindringen. Når noget erindres, forstås det på en måde, som ikke var mulig, da det skete. Ifølge dette vers er det paraklêtos' rolle at bibringe den ekstra erkendelse om Jesu ord, som ikke var til stede, da han udtalte dem. ${ }^{26}$

\subsubsection{Paraklêtos, sandheds pneuma, vil vidne $(15,26)$}

Verset fortsætter de foregående udsagn om paraklêtos, der i dette vers atter defineres som sandheds pneuma. Den udgår fra faderen, hvilket svarer til, at han sender den. Og den skal vidne ( $\mu \alpha \rho \tau v \rho \varepsilon \tilde{v} v)$ om Jesus. Ligesom disciplene skal vidne $(15,27)$. Vidnetemaet er gennemgående i Johannesevangeliet ( $f x$ 5,31-40). Vidner viser hen til Jesus for at lede til tro på ham. Således viderefører paraklêtos vidnefunktionen, idet den som de andre vidner peger på Jesus og fører til tro på ham.

26. Dette er afgørende for Jörg Freys Johannesfortolkning. Det "post-paskale" blik på den jordiske Jesus, der er garanteret ved paraklêtos-pneumas tilstedeværelse i menigheden, begrunder og berettiger den særlige johannæiske version af hans historie. I Freys Shaffer lectures er denne pointe konsekvent gennemført, jf. https:// livestream.com/accounts/565116/events/8008919 (tilgået 05.02.2018). Forelæsningerne publiceres senere i år i udvidet form. 


\subsubsection{Paraklêtos vil fælde dom over verden (16,7-11)}

Særligt i denne perikope bliver det tydeligt, at paraklêtos er en fortsættelse af Jesu virke. Endda på en sådan måde, at situationen efter Jesu bortgang og paraklêtos' komme er bedre end situationen under Jesu nærvær. Ja, paraklêtos kunne slet ikke komme, hvis ikke Jesus gik bort (16,7). Det hænger naturligvis sammen med, at Jesu gerning skal fuldbringes (jf. 19,30), så hans frelseshandling foreligger som et afsluttet hele. Det er den situation, paraklêtos skal forholde sig til, når den skal

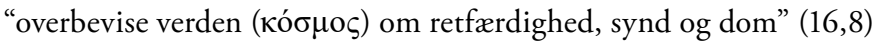

De tre begreber defineres

"om synd: at de ikke tror på mig;

om retfærdighed: at jeg går til Faderen, og I ser mig ikke længere;

om dom: at denne verdens fyrste er dømt" (16,9-11)

I denne forbindelse er det ikke afgørende at udlægge beskrivelsen af paraklêtos' virke detaileksegetisk. I al væsentlighed viderefører den Jesu egen funktion på grundlag af det fuldbragte virke. Det væsentlige er at konstatere, at den antager en selvstændig og aktiv funktion over for verden.

2.3.5. Sandheds pneuma skal vise vej i al sandhed (16,13-15)

I det sidste udsagn om paraklêtos optræder betegnelsen ikke eksplicit,

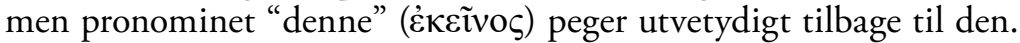
Som i 14,17 og 15,26 defineres den som "sandheds pneuma". Tilnavnet svarer til opgaven. Den skal "vise vej i al sandhed". Hvordan det foregår, fremgår af det følgende:

"for han skal ikke tale af sig selv, men alt, hvad han hører, skal han tale, og hvad der kommer, skal han forkynde for jer. Han skal herliggøre mig, for han skal tage af mit og forkynde det for jer. Alt, hvad Faderen har, er mit; derfor sagde jeg, at han skal tage af mit og forkynde det for jer" (16,13-15)

Sandheden, som sandheds pneuma skal vise vej i, er altså det, der kommer fra Jesus og derfor fra Gud. Paraklêtos' vejleder- og forkynderfunktion er videreførelsen af Jesu forkyndelse, derfor kommer det ikke fra paraklêtos selv, men fra Jesus. Dette er en herliggørelse af Jesus, fordi paraklêtos fortsætter hans forkyndelse på baggrund af hans fuldbragte virke. I denne sammenhæng skal det imidlertid blot kon- 
stateres, at paraklêtos indtager en selvstændig, aktiv funktion. Den vejleder, hører, taler og forkynder.

\subsection{Sammenfatning: Pneuma-paraklêtos i Johannesevangeliets korpus}

Som sædvanlig kan jeg ikke få alting til at gå uproblematisk op i Johannesevangeliet. De tre forestillingskomplekser er ikke umiddelbart forenelige, for de stammer fra tre forskellige sammenhænge. Et omhandler Jesu besiddelse af pneuma, hvor de centrale udsagn har direkte paralleller i Markusevangeliet. Disse udsagn markerer pneumas forbindelse til Gud. Guds pneuma er over Jesus, fordi han er den udsendte, der skal døbe med hellig pneuma. Et andet kompleks handler om pneumas rolle for de troende. Langt de fleste af disse steder refererer til menighedspraksis og gudsdyrkelse. Den afgørende pointe er, at gudsdyrkelsen skal være kongruent med den Gud, de dyrker. Disse udsagn rummer en konkret fysisk opfattelse af pneuma, som det fremgår af forbindelsen til antik filosofi og medicin. Gennem pneuma avles de troende som Guds børn, hvorfor de kan dyrke Gud i pneuma og sandhed. Dette kompleks svarer til brugen af pneuma i Første Johannesbrev. Endelig er der paraklêtos-komplekset, som angår en personificeret figur, der antager en selvstændig og aktiv rolle efter Jesu bortgang. Den skal først og fremmest være den hermeneutiske garant for Johannesevangeliets sandhed. Det er meget let at følge Pastorelli og andre i konklusionen, at den pneumatologiske refleksion, som paraklêtos-udsagnene vidner om, har sin Sitz-im-Leben i en læresammenhæng i den johannæiske menighed (Pastorelli 2006, 298).

Johannesevangelisten har tydeligvis intenderet en forbindelse mellem paraklêtos og udsagnene om pneuma, idet han anvender betegnelserne "sandheds pneuma" og "hellig pneuma" som karakteristik af paraklêtos. Netop udtrykket pneuma hagion forbinder på et niveau alle tre grupper $(1,33 ; 14,26 ; 20,22)$. Men man kan ikke se bort fra, at den personificerede fremstilling af paraklêtos ikke svarer direkte til den materielle pneuma, der er til stede i menighedens ritualer og gudsdyrkelse. Og ingen af dem er direkte sammenhængende med den pneuma, som daler ned over Jesus som en due. Hvis der er andet end en sporadisk leksikalsk forbindelse mellem dem, konstrueres den et andet sted. Her opstår spørgsmålet om prologens rolle. 


\section{Afslutning i begyndelsen: Johannesprologen}

I den stoiske tolkning af prologen kan man finde et grundlag for den sammenhæng i den johannæiske forståelse af pneuma og paraklêtos, der efter min mening ikke findes i evangeliets korpus. Det pointeres af navnlig af Engberg-Pedersen, at logos og pneuma ifølge stoikerne er to sider af samme sag. Logos er den kognitive side, der bevirker forståelse og erkendelse; pneuma er den fysiske side, der transformerer kødelige kroppe. De to hænger uløseligt sammen. ${ }^{27}$

En kendt definition af den stoiske pneuma stammer fra Aetius:

The Stoics declare that God is an intelligent, designing (lit. "artistic," Gr. $\tau \varepsilon \chi v i \kappa o ́ v)$ fire which methodically proceeds towards creation of the world and encompasses all the seminal principles according to which everything comes about according to fate, and a breath $(\pi v \varepsilon \tilde{v} \mu \alpha)$ pervading the whole world, which takes on different names owing to the alterations of the matter through which it passes. ${ }^{28}$

Den pneumatiske sammenhæng mellem Gud, universet og mennesket giver sig også til kende i menneskets moralske fornuft, der netop består $\mathrm{i}$ at være $\mathrm{i}$ overensstemmelse med de universelle, guddommelige love, der findes i alting:

Living according to virtue equals living according to one's experience of the things that occur naturally, as Chrysippus says in his On Ends. For our natures are parts of the nature of the whole. That is why the end consists in living in accordance with nature, that is to say, both according to one's own [sc. nature] and to that of the whole, while doing none of the things prohibited by the common law, which is the right

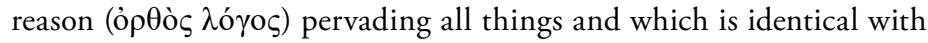
Zeus, who presides over the government of all reality. [He holds that]

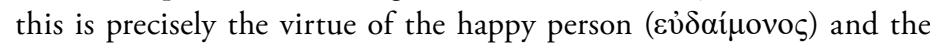
smooth flow of life, namely when everything is done in harmony bet-

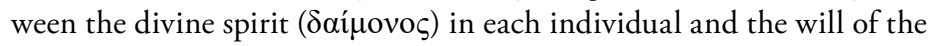
ruler of the universe. ${ }^{29}$

Det forekommer åbenlyst, at en stoisk filosof ville se sammenhængen mellem pneuma og logos, idet logos' mange betydninger alle er

27. Engberg-Pedersen (2017), 62f. Vedr. den stoiske pneuma, se Teun Tieleman, "The Spirit of Stoicism," Frey \& Levison (2014), 39-62.

28. Aetius 1.7.33 = SVF 2.1027; LS 46A. Citeret efter Tieleman (2014), 41.

29. Diog. Laert. 7.87-88 = SVF 3.4. Citeret efter Tieleman (2014), $53 \mathrm{f}$. 
forbundet med den guddommelige pneuma. Origenes tilkendegiver eksplicit, at stoikerne mener

the logos of God, which descends ( $\kappa \alpha \tau \alpha \beta \alpha i v \varepsilon i v)$ as far as human beings, even the lowest ones, is nothing other than material spirit $(\pi v \varepsilon \tilde{v} \mu \alpha$ $\sigma \omega \mu \alpha \tau \iota \kappa o ́ v) .{ }^{30}$

Læser man Johannesprologen på denne baggrund, vil det johannæiske logos helt naturligt blive forstået i overensstemmelse med den stoiske pneuma. ${ }^{31}$ Prologens udsagn om logos' evighed og guddommelighed $(1,1 \mathrm{f})$, dens skabelsesaktivitet $(1,3.10)$, og at den er livgivende og oplysende $(1,4 \mathrm{f} .9)$ falder helt i tråd med den stoiske pneuma. ${ }^{32}$ Logos er den altgennemstrømmende rationalitet, der er identisk med Gud. Derfor sætter logos mennesket i stand til at leve i henhold til Guds mening. Det logos er identisk med den materielle pneuma.

Med denne læsning af prologen giver udsagnene om logos vejledning i, hvordan pneuma-udsagnene i evangeliets korpus kan forstås i sammenhæng. Inkarnationsverset $(1,14)$ er grundlag for Jesu besiddelse af pneuma. Som det inkarnerede logos har den johannæiske Jesus også pneuma. For de to dele forstås som et og det samme. ${ }^{33} \mathrm{Han}$ er logos/pneuma. Mennesket Jesus er altså den guddommelige rationalitet og materialitet, som gennemstrømmer hele skabelsen, men som mennesker ikke forstår og ikke modtager $(1,10 \mathrm{f})$. Havde de gjort det, ville de være i en radikalt anden eksistensform. De ville ikke være i mørket $(1,5)$ eller i verden (johannæisk forstået, jf. fx 15,18f; 17,14-16) (1,10), men i overensstemmelse med Gud. Det udtrykker prologen således, at de, der faktisk tager imod logos/pneuma i men-

30. Contra Celsum VI, 71 = SVF 2.1051. Citeret efter Engberg-Pedersen (2017), 62 n. 29.

31. Spørgsmålet om den religionshistoriske baggrund for det johannæiske logosbegreb er naturligvis stærkt omdiskuteret. U. Schnelle har formentlig ret i, at der ikke findes en monokausal forklaring. Udo Schnelle, Das Evangelium des Johannes, ThHK 4 (Leipzig: Evangelische Verlagsanstalt 1998), 32. Det betyder også, at logosbegrebet vil være åbent for en række forskellige læsninger, jf. Jörg Frey, "Between Torah und Stoa: How Could Readers Have Understood the Johannine Logos", The Prologue of the Gospel of John. Its Literary, Theological, and Philosophical Contexts. Papers read at the Colloquium Ioanneum 2013, red. Jan G. van der Watt, R. Alan Culpepper \& Udo Schnelle, WUNT 359 (Tübingen: Mohr Siebeck 2016), 189234.

32. I Salomos Visdom findes en lignende overtagelse af stoiske forestillinger i forbindelse med fremstillingen af sophia. Engberg-Pedersen (2017), 63-65.

33. Men dermed ikke være sagt, at pneumas inkarnation finder sted i Jesu dåb. Jeg har svært ved at forstå Johannesevangeliets omfortolkning af Johannes (Døbers) rolle og omkalfatring af dåbsscenen, hvis ikke den johannæiske Jesus allerede har en anden karakter, da han kommer til Johannes (jf. min udlægning ovf.). 
nesket Jesus, bliver Guds børn $(1,12) .{ }^{34}$ Således forbindes de troendes forhold til logos/pneuma med deres egen identitet, som den bliver til gennem menighedens praksis. Det er gennem fødslen i pneuma, at de troende bliver Guds børn. De er netop ikke født kødeligt af kvinder og mænd, men af Gud $(1,13)$. Således bliver de troendes genfødsel ved den materielle pneuma i menighedens ritualer en konsekvens af Jesus som logos/pneuma. Endelig er paraklêtos' funktion som formidler af den uddybede erkendelse og sande forståelse af Jesus et udtryk for logos/pneumas kognitive side. Fordi pneuma/logos er den guddommelige rationalitet, er pneuma sandhedens pneuma, hvis tilstedeværelse medfører den fuldstændige forståelse. Det er paraklêtos udtryk for, idet den personificerer pneumas rationelle del. Det er gennem denne pneuma, at den rette forståelse af Jesus og hans forkyndelse fremstår. I prologen kommer den rationelle del af pneuma til udtryk, når det

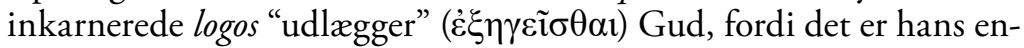

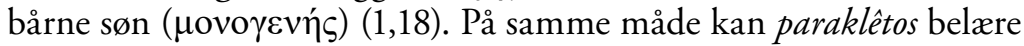
om Jesus, fordi den er et udtryk for den rationelle del af pneuma, som er i menigheden.

Læses prologen på denne måde, kan den betegnes med A. von Harnacks udtryk: en indledning til hellenistiske læsere. ${ }^{35}$ For den læser, der kender forholdet mellem logos og pneuma, ${ }^{36}$ vil prologen fungere som en læsevejledning, der skaber sammenhæng i udsagnene om pneuma. ${ }^{37}$ Evangelisten har på den måde forsøgt at etablere en enhed af de forskellige forestillinger fra forskellige sammenhænge. I evangeliets korpus hænger de ikke organisk sammen, men prologen giver den filosofiske læser en ramme for at forstå dem inden for én konception.

Prologen er således en indledning. Den skal styre læsningen af evangeliets korpus, så dets fortælling om Jesus forstås i overensstemmelse med den præsentation af logos, som læseren møder indlednings-

34. Se Engberg-Pedersens læsning af Joh 1,1-5 som normativ kosmologi, EngbergPedersen (2017), 51-53.

35. Adolf von Harnack, "Über das Verhältnis des Prologs des vierten Evangeliums zum ganzen Werk," ZThK 2 (1892), 189-231 (230). Bortset fra den formelle opfattelse af forholdet mellem prologen og evangeliet, at prologen skal forberede den hellenistiske læser til evangeliet, bidrager Harnacks læsning dog ikke med noget i denne sammenhæng.

36. Jeg holder altså fast $\mathrm{i}$, at netop denne meget vigtige identificering af logos og pneuma ikke finder sted i Johannesevangeliet, men er en præmis for læsningen, som den filosofisk oplyste læser deler, jf. Nielsen, “Johannæisk filosofi?”, DTT 80 (2017), 51-69 (69).

37. Udtrykket 'læsevejledning' er taget fra Michael Theobald, Die Fleischwerdung des Logos. Studien zum Verhältnis des Johannesprologs zum Corpus des Evangeliums und zu 1 Joh, NA 20 (Münster: Aschendorff 1988) uden at overtage hans litterær- og teologihistoriske konklusioner. 
vist. Som det er tilfældet med de fleste indledninger, kan man bedst forestille sig, at den er blevet til efter korpus. Forfatteren vil dermed sikre sig en bestemt læsning af sit værk. Det er formentlig også tilfælde i Johannesevangeliet. Det er ikke nødvendigvis sådan, at prologen er en reaktion på en bestemt læsning af evangeliets korpus. ${ }^{38}$ Der er ikke diskrepans mellem prolog og korpus. Tværtimod har evangelisten forsøgt at skabe entydighed ved at introducere et filosofisk begreb om Jesus, der for den filosofisk orienterede læser sammenfatter ellers adskilte forestillinger.

Man kan sige, at forsøget på at skabe enhed og entydighed ikke er lykkedes i overvældende grad. Men man kan også sige, at Johannesevangeliets tekst trods dets forsøg på ensretning er åben for forskellige læsninger. De uendeligt mange modstridende læsninger er bevis på begge dele.

38. Det er Theobalds pointe, at prologen er en reaktion mod de johannæiske modstanderes dualistiske dåbskristologi (jf. 1 Joh), som de fandt i evangeliets korpus. Theobald (1998), 477-489. 